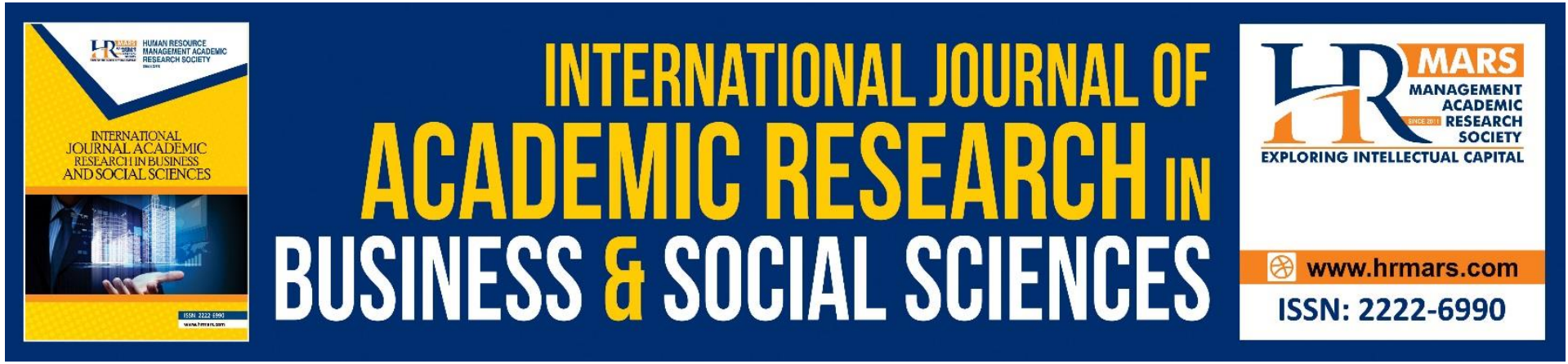

\title{
A Review on Participatory Ergonomic Approaches: What 'Participants' mean to the Organization?
}

Mohd Nasir Selamat, Rusyda Helma Mohd, Mukhiffun Mukapit, Siti Fardaniah Abdul Aziz \& Nik Hairi Omar

To Link this Article: http://dx.doi.org/10.6007/IJARBSS/v11-i8/10068

DOI:10.6007/IJARBSS/v11-i8/10068

Received: 18 June 2021, Revised: 21 July 2021, Accepted: 02 August 2021

Published Online: 16 August 2021

In-Text Citation: (Selamat et al., 2021)

To Cite this Article: Selamat, M. N., Mohd, R. H., Mukapit, M., Aziz, S. F. A., \& Omar, N. H. (2021). A Review on Participatory Ergonomic Approaches: What 'Participants' mean to the Organization? International Journal of Academic Research in Business and Social Sciences, 11(8), 612-627.

Copyright: @ 2021 The Author(s)

Published by Human Resource Management Academic Research Society (www.hrmars.com)

This article is published under the Creative Commons Attribution (CC BY 4.0) license. Anyone may reproduce, distribute, translate and create derivative works of this article (for both commercial and non-commercial purposes), subject to full attribution to the original publication and authors. The full terms of this license may be seen at: http://creativecommons.org/licences/by/4.0/legalcode

Vol. 11, No. 8, 2021, Pg. 612 - 627

Full Terms \& Conditions of access and use can be found at http://hrmars.com/index.php/pages/detail/publication-ethics 


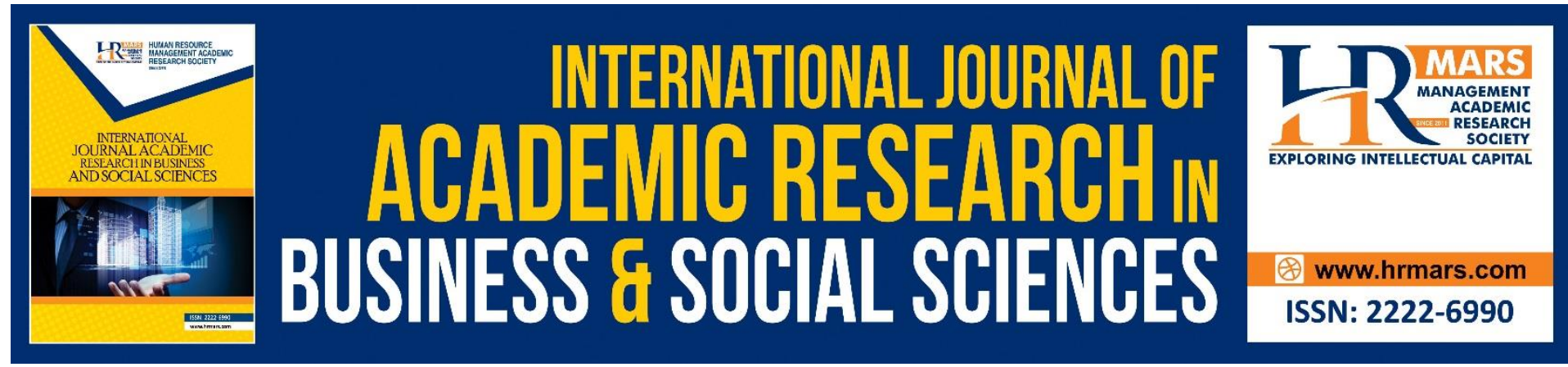

\title{
A Review on Participatory Ergonomic Approaches: What 'Participants' mean to the Organization?
}

\author{
Mohd Nasir Selamat ${ }^{1}$, Rusyda Helma Mohd ${ }^{1}$, Mukhiffun \\ Mukapit $^{2}$, Siti Fardaniah Abdul Aziz ${ }^{1}$ \& Nik Hairi Omar ${ }^{1}$ \\ ${ }^{1}$ The National University of Malaysia (Selangor, Malaysia), ${ }^{2}$ Technical University of Malaysia \\ Melaka (Melaka, Malaysia) \\ Email:md_nasir@ukm.edu.my
}

\begin{abstract}
The involvement of various parties in making work decisions in the organization can have a positive impact. Participation in implementing ergonomics aspect among management and individual level will enable workers to serve to the conformity of the job rather than in adjusting to the environment. Hence, it will avoid emerging problems especially to the workers such low self-effacing, work pressure and job dissatisfaction, low level of health status, which eventually affects workers and organizational performance. The important of understanding the multidimensional, dynamic characteristics of participations and the potential positive and negative impact on the ergonomic work system and workers is emerging. Thus, the main agenda of article is to explore conceptually the roles of numerous participants' ergonomics approaches included examining the potential negative impact of participation. This paper systematically assesses methodologic aspects of literature reviews which references are made on related studies since 1986 to 2021. The present empirical studies and published in high-impact, peer-reviewed academic journal that indicate the significant of participatory ergonomics in the organisations has been analysis. It is also covers several studies from local and abroad context. Electronic bibliographic databases, conference proceedings, and reference registers were systematically searched to obtain relevant documents. The review described important trends in the literature, including increased attention to be given in implementing participatory ergonomics in the organisations. The review analysis were reported that focus of participants among workers improved task contents, increase quality of working life, enhance workers health, and produce accurate ergonomic workstation as well as increase productivity. Conversely, raise cost of operation, added workforce supply as well as increase workload and work pressure was contributed as adverse impact of participants. Most studies were also mentioned that the implementation of participatory ergonomics contribute to both workers and organizational in term of wellbeing and wellness. Finally, the rules as 'participant's approaches in organization are essential for employees and the organization to achieve foster quality performance. Further empirical study is required on the implementation of participatory ergonomic as one of an initiative to improve workers capabilities and organisation competencies.
\end{abstract}


Keywords: Participatory Ergonomics, Occupational Safety and Health, Workers and Organisations Performance.

\section{Introduction}

Occupational safety and health (OSH) issues has always been the subject of discussions across the world as a way of providing a good working environment at the work as well as contributing to enhance workers health. Related to OSH, issues of ergonomics at the workplace have less attention (Fatin \& Selamat, 2020; Wern \& Selamat, 2019; Sandra, Beach, Aw \& Sheikh-Ahmed, 2001; Zafir, 2009). Some people believe that ergonomics is a new idea. However, the fact is that the concept of ergonomics has been around for very long time. Issues of ergonomics present an interesting area of study that can bring benefits to workers and organizations. Introduction to ergonomics is especially important for organizations involved in the production and manufacture of products or goods. In general, ergonomics means the interaction between humans and the surrounding environment that involves occupational safety and health features (Selamat, 2016). Performance improvement can occur when there is interaction between humans and the surrounding environment which included an organization responsibilities to provide a good and better working environment at work.

In addition, the organization is an important aspect in measuring the relationship between ergonomic aspects and occupational safety and health performance. Therefore, in order to measure the ergonomic aspects in the workplace, ergonomic involvement or participatory ergonomics needs to be involved by the organization in the workplace. This can be seen when an organization accepts new technological changes and the company provides support to employees on technological innovations by sending employees to undergo training and supervision directly from supervisors on the changes. This causes employees to be more motivated to do the job. Furthermore, employees will tend to be motivated and enthusiastic when the organization provides a career development opportunity to their employees (Smith \& Carayon, 2009).

Meanwhile, shift work arrangements and overtime can cause employees to be in a negative mental state as well as declining health performance (Selamat, 2016). It is estimated that 20 to 30 percent of workers do not like to work shifts because of difficulty sleeping (insomnia), disorders of the digestive system and mental function, which eventually leads to stress. According to Ghoudarzi et al (2019) showed a significant relationship between occupational safety and health management in non-governmental rehabilitation centres and their employees' job satisfaction was at a moderate level. Moreover, this can also be seen in a study by Gyekye (2005) stating that organizations have a significant relationship on occupational safety and health performance.

Therefore, the importance of ergonomic elements must be emphasized by employers and employees so that good effectiveness can be obtained by the organization. In specific can be consider as participatory ergonomics at work, which includes self-involvement (the feel of volunteering involvement with ergonomics aspect), knowledge base (the knowledge of ergonomic aspects), managerial support (organisation sustaining ergonomics aspect), employee supportiveness (encouragement to implement ergonomics aspect), and strain (refusal of ergonomics aspect) (Selamat, 2016).

Moreover an emphasis should be given to avoid problems such as poor quality work results from imperfect facilities, narrow workspaces causing uncomfortable workers, unmanageable workload, expose to hazards, dangerous and unsafe work environment. Due 
to that, the existence of an ergonomic element that is appropriate and meets the needs of work activities must be created to ensure the continuity of each work activity is safe and healthy in implementing the goals of an organization (Bridger, 2003). Therefore, the organization and employers need to emphasize the aspects of occupational safety and health to improve and launch the continuity of activities in the organization.

\section{Ergonomic at Work}

In general, ergonomics is defined as the interaction between people and machines, and the factors that affect this interaction (Alexander, 1986; Bridger, 2003; Carayon, Xie, \& Kianfar, 2013; Dempsey, Wogalther, \& Hancock, 2000; Mavis, Abdul-Rahman, \& Mohd-Tamrin, 2014; Selamat, 2016). Ergonomics actually means to fit the task to the individual, rather than the individual to the task (Fernandez, 1995; Selamat et al., 2020). According to Archer, Borthwick and Tepe (2005) ergonomics is considered a science, which deals with the interaction among humans and their activities, equipment, environment, and systems. Its purpose is to improve the performance of systems and workers to contribute to an increase in the productivity of an organization. Ergonomics takes into account several aspects such as human behavior, capabilities, and limitations as well as the design of systems, machines, tools, task and jobs, and environmental productivity, safety and effective human use (Ashraf, et al., 2002; Carayon, 2009; Hermans \& Peteghem, 2006; Loo \& Richardson, 2012; Selamat \& Surienty, 2012; Shaliza et al., 2009). Thus, ergonomics attempts to optimize human well-being and overall system performance.

According to Fernandez (1995); Gundage and Janis (2014); Helander (1997); Parsons (2000) ergonomics applies the knowledge of human abilities and limitations to design systems, organizations, jobs, machines, tools, and consumer products for the sake of safe, efficient, and comfortable human use, while ensuring the safety, health, and wellbeing of workers. Based on these definitions, three elements prevail; comfort, health and productivity for individuals and organization.

Ergonomics implementation in organisation will lead to: (1) increased productivity, (2) improved health and safety of workers, (3) lower worker compensation claims, (4) compliance with government regulation (e.g. OSHA standards), (5) job satisfaction, (6) increased work quality, (7) lower worker turnover, (8) less lost time at work, (8) improved morale of workers, and (10) decrease in absenteeism rates (Carayon \& Smith, 2000; Fernandez, 1995, Jalaluddin, 2007; Noblet \& Lamontagne, 2006; OSHA, 1994; Rowan \& Wright, 1994; Selamat, 2016; Selamat et al., 2020; Shaliza et al., 2009; Yakubu \& Bakri, 2013; Yeow \& Rabindra, 2003; Zafir, 2008; Zafir et al., 2013).

According to Angela (2000); Zafir et al (2008) indicate that ergonomics can affect workers physically and psychologically since efficient tools, better designs of machines, and factors contributing to comfortable environment will be conducive to improved results in job design. Conway et al. (2008) also mention that through good ergonomics implementation, problems related to physical and psychologically can be avoided. This is supported by Mansfield and Amstrong (1997); Sheley (1995) who found that the application of ergonomics has gained recognition among corporations as they have sought to address rising medical expenses, higher workers' compensation claims, and lower productivity due to workers' accident and physical injury. Therefore, studies indicate that ergonomics could reduce workers strain/stress as well diminish other factors which hinder performance. Other studies reported that through implement ergonomics aspects at workplace will enhance workers and organizational productivity and efficiency (Kogi, 2015; Mohd Azman \& Selamat, 2019; Azreen 
\& Selamat, 2020). Thus, part of ergonomics aspect can be referred as participatory ergonomic (PE) which commonly known as indicators to assist an improve ergonomics aspects of work at the workplace which eventually avoid any related occupational and safety health issues at work (Nagamachi, 1995; Kogi, 2006; Selamat, 2016).

\section{Methodology}

Reference is made to participatory ergonomics -related studies since 1986, which present models and theories demonstrating the importance of participatory ergonomics in the workplace. Specifically, this method covers several studies from local, abroad and uses through manuals. The present empirical studies and published in high-impact, peer-reviewed academic journal that indicate the significant of participatory ergonomics in the organisations has been analysis. Electronic bibliographic databases, conference proceedings, and reference registers were systematically searched to obtain relevant documents. Electronic databases include publication of articles such as in Ergonomic Abstract Online, Scopus, ProQuest Digital Dissertations, Foreign Doctor Dissertation and Thesis and other related sources Proceedings from various conferences, books and textbooks, news reports and available documents have also been reviewed manually.

The first stage is to analyse and study the conceptual basis of participatory ergonomics including definitions through experts in the field and through various other studies. A comparison of several definitions will be issued with operational definitions appropriate to this study. What's more, key concerns in participatory ergonomics include self -involvement, knowledge base, management, employees, and stress. Therefore, further explanation will be discussed below.

In addition, in the analysis of this concept also participated, added interest, related to the participatory ergonomics of employees and organizations. In addition, the following discussion will be some of the negative effects on participatory ergonomics implemented in the workplace. Next the writing will conclude with a general discussion related to employment in the workplace and suggest for the future. Finally, the purpose for the main writing of this concept analysis writing is to reveal the parties involved in the employees and the organization and the other parties will benefit together when carrying out the work in the job in the face of future job challenges.

\section{Implementation Participatory Ergonomics at Workplace}

$\mathrm{PE}$ is designed to assist processes in the organization to demonstrate good performance in terms of technical or management problems that will help create employee well -being in the organization. Several organizations use different approaches to ensure the continuity of organizational development does not become backward. These methods are widely recognized as methods for promoting initiative to employees and achieving solutions to a variety of unpredictable problems in the workplace (Vink et al., 1995; Kogi, 2006; 2010). According to Kuorinka (1997); Wilson and Haines (1997) state that problems in the workplace can be solved by applying PE. This method requires the participation of several parties either within or outside the organization that perform work activities by using a problem -solving approach to reduce risk factors.

PE produces employee satisfaction with workplace redesign as well as gains in product quality and productivity improvement (Nagamachi, 1995), which ultimately influences the development of employee and organizational performance. Moreover, the effectiveness of $P E$ interventions has been proven successful in improving health outcomes (Rivilis et al., 
2008). Base on Wilson and Haines (1997) define participatory ergonomics as the involvement of people in planning and controlling a significant amount of their own work activities, with sufficient knowledge and power to affect both processes and outcomes in order to achieve desirable goals. Participatory ergonomics is also described as a concept involving the use of participative techniques and various forms of participation in the workplace (Kogi, 2010; Vink \& Wilson, 2003). In short, participatory ergonomics encourages workers to be involved in controlling their own work activities, participating in decision making, thereby decreasing work organization or psychological risk factors (Wilson \& Haines, 1997; Selamat, 2016).

Participatory ergonomics in a workplace will help to reduce the problems; such as absenteeism, stress, staff turnover, and pressure, dissatisfaction, avoid any hazard and injuries, occupational accidents, as well as increase job performance (Jong \& Vink, 2002; Kogi, 2006, 2012a, 2012b; Punnet et al., 2013; Rivilis et al., 2008; Selamat, 2016; Vink, et al., 1995). On the other hand, the implementation of participatory ergonomics in the workplace is not getting much consideration in most companies, especially developing countries where manufacturing companies are concerned (Selamat, 2016). Consequently, the most appropriate strategy left is to achieve a target of participatory ergonomics implementation.

However, the changing methods of work cause difficulties and require more time to make it easy. Not many organizations are considering implementing PE in improving performance and also to solve problems especially in terms of employee safety and health. Vink et al (1995); Selamat (2016) report that employees find PE difficult to accept, require high costs, or sometimes employees feel bored and may be reluctant to use new work methods. Nevertheless, Wilson et al (2005); Noro and Imada (1991) mention that by involving employees during the change process in the organization can help overcome problems that occur such as decision -making difficulties and re -planning of workstations. Therefore, the main agenda of this study is to analyse the role of PE including examining the possible negative effects of the implementation of PE.

In measuring participatory ergonomics, several studies have conceptualized it to be multi-dimensional. The most used or one that has been used consistently in the past measure participatory ergonomics along to self-involvement, knowledge base, managerial support, employee supportiveness, and strain (Matthews et al., 2011; Selamat et al., 2020). These elements were test to several companies in order to define the best measurement of participatory ergonomic at work. Thus, through these five elements of participatory ergonomic, represent several contexts and issues of implementation ergonomics aspect in the organisations.

Self-involvement refers to the level of interest of workers in implementing ergonomic aspects at work. This means workers will be concerned about and comprehend the implementation of aspects of ergonomic at workplace. Knowledge base concerns initiatives to improve knowledge of ergonomics and access to information while conducting work. Hence, managerial support can be referred to as the responsibility of employers in implementing aspects of ergonomic in the workplace, as well as their encouragement in this regard. The organization is also considered accountable for promoting the benefits of ergonomics at work. Moreover, employees' supportiveness refers to workers' attempts to accept and familiarise to aspects of ergonomics while performing their task. Finally, the amount of strain experienced because of the implementation of ergonomics at workplace will either have a positive or negative impact on workers while performing their tasks.

The implementation participatory ergonomics at work shows several benefits, including an increase in the quality of working life, providing accurate ergonomics 
workstations, and improving task contents and worker health (Matthew et al., 2011; Saurabh et al., 2014). According Kuorinka (1997) and Kuorinka and Patry (1995) reported that participatory ergonomics helps management to deal with uncertainty and to manage complex situations in designing manual tasks. In addition, it increases the value of product and adds realism to complex systems design in organizations. Participatory ergonomics also facilitates the process of division of labour and control of efficient work in organization where it has been revealed that workload could be decreased (Nagamachi, 1995). For example, by involving workers opinion and idea, such as the appropriate duration in conducting task from four hour nonstop to four hour with one time rest in 10 minutes, it bring positive reaction to the workers which feel more ease and satisfaction in performing their task.

Research by Kogi (2006) about ergonomics in the workplace shows improvement through implementation of participatory ergonomics in different settings. Kogi's found that good workstation design enables work efficiency, easier work, easy reach over desk space, and more flexible working environment among the workers. Moreover, extended study was done look on the relationship between participatory ergonomic and health practice as well as workplace stress (Kogi, 2012; Kogi et al., 2015). Result of these studies reported that more effort needs to engender for establishing participatory ergonomics to all workplace as much benefit were produce such as improve workers health and reduce cost of operations. Hence, according to Kogi et al (2015), in promoting stress prevention at work, it is suggested to develop and use participatory tools incorporating multifaceted checkpoints focusing on local needs of improving ergonomic at work. As consequences, the important of implementation participatory ergonomics must be given attention since it beneficial to others.

Additionally, supported form other study refers to the workers' health where it has provided partial to moderate evidence that participatory ergonomics interventions could have a positive impact on musculoskeletal symptoms, thereby reducing injuries and the number of workers' compensation claims and lost days of work or sickness absence (Eerd, et al., 2010). Goes to the study by Tappin and friends (2016) indicated that participatory ergonomics approach should be applied at an industry level to develop MSD interventions with involvement of stockholder and the key person of organization. Similarly with the recent study found that participatory ergonomic interventions can be a feasible and actual approach to decrease the exposure to work related risk factors for WMSDs in industrially developing countries (Marcos et al., 2021). Moreover, other study were also found that implementation of participatory ergonomic had been a decreased of risk due to work injury, lost time injury, and total day injury of time loss (Evanoff et al., 1999; Fatin \& Selamat, 2020; Jia Wern \& Selamat, 2019; Mohamad Syahmil \& Selamat, 2020).

Research by Tsutsumi et al (2009), which explores the effects of participatory intervention for workplace improvement, has shown that good participatory intervention in the workplace is effective against deterioration in mental health and job performance. In addition, participatory ergonomics were significant in reducing complaints about pain, with a concurrent improvement in job satisfaction, increase productivity, quality of cones, and amount of residual fibre (Maciel, 1998). This study was done at a synthetic fibre section of a chemical plant and focused on tackling the problem of increasing repetitive strain injuries among workers. The study by Mahdavi, Shafiee-Motlagh and Darvishi (2019) has mentioned that the interventions using participatory ergonomics was reduced the intensity of repetitive tasks and force in the areas of the hands, shoulders and lower back. In addition, Rivilis and colleagues (2006) prove that participatory ergonomics programme has a positive impact on musculoskeletal symptoms, reducing injuries and workers' compensation claims, which lead 
to a reduction in lost days from work or sickness absence. On the contrary, Cole et al (2005) found that there is no effect an effort on physical and sicknesses among workers.

A study by St-Vincent et al (1998) researched the implementation of participatory ergonomics at two industries in the electronics sector. Joint ergonomics groups were used in the study in which workers and technical representative were given opportunities to implement participatory ergonomics concepts, such as training program. The result showed that there was an almost $78 \%$ reduction in postural stresses, force requirements or mechanical stresses, all of which greatly assisted in the upgrading of worker performance. In short, through providing support and reassurance the organization will improve worker productivity and well-being.

Several studies have proved that participatory ergonomics will facilitate the process of division of labour and control of systematic work in organization (Nagamachi, 1995). This study has done at Daikin Company, which provides manufacturer small and large sized air conditioners on 1985 , found that through implemented participatory such equipment as hoist, monorail, table lift, and auto- carrier were shown eliminated and the work burden was decreased. In addition, the project team who are handled the work finally obtained a $25.2 \%$ increment in the productivity. Besides that, Nagamachi propose second project at 1988 on implemented participatory ergonomics at workplace which connect to Industrial Engineering staff found that, PE implementation resulted in keeping all good performance while $45 \%$ productivity increase.

In addition, Sundin, Christmansson, and Larsson (2004) has report on their study that through implement participatory ergonomics in product development process in a bus manufacturing company were potential for facilitating communication and co-operation among workers and those are connected in the task process. Moreover, Sundin and friends (2003) were used that gathered a group of designers and production engineers from the different plants, including also ergonomics researchers. The collaboration among them assist bus manufacturing company solve several problem related the organizations. Therefore, participatory ergonomics approach has a potential to improve assembly productivity and ergonomics as well as offer a better understanding among product designers and production engineers in product development processes. Therefore, relationship between them will expose a good working environment such on aspect of psychosocial at workplace.

Others study by Cole et al (2005) found that they have changes after proper implementation on participatory ergonomics having done the four worksites with the different companies while using the same approaches. In this study, Cole and colleagues (2005) try to examine the process, implementation, and effect of participatory ergonomics at workplace. However, study found that there is no effect an effort on physical and sicknesses among workers. This study contradicted with other studies that has been done and it might due to the readiness of organisation in implementing participatory ergonomics at work.

In addition, studies have done at one depot of large courier company with involved 122 employees, used questionnaire method with pre and post-test (Rivilis et al., 2006). The main objectives on this study are to access the process of implementation, changes in risk factors, and changes in MSD health outcomes. Through this study found that there have changes on health outcome of workers, increase levels of job influence and communication, which were associated with, reduce pain intensity and improved work role functions as well as reduce low level of pain. Finally, participatory ergonomics can improve risk factors related to WMSD and meaningful workers participations in the process are important aspects for the success of such interventions (Rivilis et al., 2006). In short, Rivilis and colleagues (2006) has 
proven that participatory ergonomics intervention have a positive impact on musculoskeletal symptoms, reducing injuries and workers' compensation claims and a reduction in lost days from work or sickness absence. Same goes to a study by Sara and Feradica (2017) which participatory ergonomics intervention positively influences the perception of workers concerning the level of fatigue and repetitiveness and increasing job satisfaction with a positive impact on productivity. Therefore, finally, it obvious that through implement participatory ergonomics at the industrial area will assistance to improve workers health, which eventually leads to increase organizations performance. It is also influence by a good workstation itself at the workplace.

Moreover several studies report that increasingly applied participatory ergonomics method were help in workplace improvement including risk management processes in both industrially developed and developing countries (Hignett et al., 2005; Kogi, 2002; Priyoko Prayitnoadi et al., 2019: Shanavaz, 2000) as well as on the safety and health risk reduction process at different workplaces (Khai et al., 2005). For example, studies by Richardson and Hignett (1994) regarding the use of participatory ergonomics in risk management project for MSDs. Result shows that participatory ergonomics could be used to evaluate changes in understanding and behavior of people at work as far as risk management in concerned. Additionally, many studies also address MSDs in a wide range of industries, which lead an improving organizational productivity through a goodness of workers health and safety (Westgaard \& Winkel, 1997). Similar study have shown that studies provided partial to moderate evidence that participatory ergonomics interventions could have a positive impact on musculoskeletal symptoms, on reducing injuries and workers' compensation claims and on lost days from work or sickness absence (Eerd et al., 2010). Therefore, several aspects from an organizational perspective, such as the physical working environment, having a participative supervisor on duty, as well as implementing an ergonomics program at work, might have a great influence on occupational safety and health performance (Selamat, 2016). It will also predict any likelihood of problems in organization that can be addressed and overcome at an early stage. The involvement of employees and management commitment are the two most important factors to consider which is needed to help employees, ergonomists and OSH staff effectively implements ergonomics in the workplace (Broday, 2020; Burgess-Limerick, 2018; Priyoko Prayitnoadi et al., 2019).

Based on these analyses has shown that the implementation of participatory ergonomics has shortcomings that encourage organizations not to participate in the implementation of participatory ergonomics activities in the workplace. Although the percentage of positive effects of participatory ergonomics interventions shows higher than negative effects, efforts to further reduce the percentage of negative effects need to be made. Moreover, based on Hignett et al (2005); Selamat et al (2020) there are two main reasons why participatory ergonomics is not given attention in the organization that is due to the lack of quality assessment of the implementation of participatory ergonomics in the organization. The organization is not interested in evaluating the results of programs or projects that are not encouraging. Further, the organization does not see the need for evaluation if the project and program are successful. This is due to the limited knowledge of the organization's managers in implementing effective participatory ergonomics methods. Therefore, organizations need to implement best practices in evaluation programs or other project activities by implementing participatory ergonomics in the workplace.

In addition, the negative effects of participatory ergonomics implementation in the workplace can be viewed from a variety of different angles. Things that are often a concern 
of organizational management are such as increased operating costs, the need for leadership or chief executive aspects, increased workload and work stress (Selamat, 2016; Selamat et al., 2020). A large number of large and well -known organizations do not face problems while implementing participatory ergonomics in the workplace. Each year they allocate a budget to implement participatory ergonomics in the workplace as required by higher organizational management. On the other hand, for medium and small organizations were identified to have limitations to implement participatory ergonomics in the workplace due to limited operating budgets (Marcos et al., 2021; Prayitnoadi et al., 2019; Selamat, 2016). Therefore, such matters will be hindered in the implementation of participatory ergonomics in the workplace.

Hence, the worst thing is it will contribute to another major problem at work such as work pressure, sickness absence, intent to quit from work, effect to workers health, which consequently reduces workers performance. Low level of work satisfaction and job loyalty will emerge since the pressure of work increase. Additionally, this situation will affect the accomplishment of organization productivity and efficiency. Thus, this seem like the occurrence problem will reoccur when the implementation of participatory ergonomics do not in the correct method.

Various methods can be used in implementing participatory ergonomics in the workplace. Among them requires techniques, precise systems, and even modules, which can guide organizations to implement participatory ergonomics in the right way. This means the resources to implement participatory ergonomics need to be given attention. For example, the improvement of ergonomic elements needs to be done which is a process of evaluation and reproduction such as the exchange of new equipment or machines. This situation pushes the organization to incur the associated costs and requires the assistance of others in this work process. Therefore, it is clear that this situation will increase operating costs as it requires many processes and approaches that will result in improved management of work activities.

Studies have suggested that for the starting to implement participatory ergonomics at work, it is necessary to have an expert that can handle the process (Eerd et al., 2010). The development of special committee also needs to encourage the participation of workers in implementing participatory ergonomics at work. Supportiveness and involving from management and subordinate is desires. Other than that, awareness of potential facilitators and barriers is extremely important in the initiation, ongoing process and implementation of participatory ergonomics at work (Eerd et al., 2010).

According to Eerd and friends (2010), the common term describing in a PE process included, support of PE program, ergonomic training/knowledge, and creation of appropriate team, communication, and organizational training/knowledge. For that reason, the demand of work and individual workers will raise which eventually may lead to increase cost of operation as well as increase workload. For example, organization establish the rules to force employee to participate on activities that organized by the committee that handled PE program such as, training program. Some of workers felt disappointed because they think as burden and do not considered as routine job that they should be involved as workers.

\section{Conclusion}

This analysis shows that the implementation of participatory ergonomics in the workplace is among the best of the best that can improve the performance of employees and the organization. This participatory ergonomics implementation is also able to offer additional organized work systems. Organizational members, consultants and experts in the field of 
ergonomics can be involved in the implementation of participatory ergonomics in the workplace, further requesting effective inputs to be implemented in the organization. In addition, the active involvement by participating and cooperating with any management as well as employees will greatly help in the management and operation of the organization. In line with workplace employment, it must be implemented as quickly as possible by employing employees at all levels of the organization, as well as promoting organizational learning for the future (Matthews et al., 2011).

Therefore, it is suggested that the positive relationship between participatory ergonomics and organizational performance as well as employee performance has been proven as one of the indicators in helping workplace development. These include the implementation of the ergonomic aspect itself, the improvement of the content and requirements of the task, the improvement of employment, the improvement of employee health, the provision of training programs and good work plans in the workplace. From a different angle, the negative impact of time on employee performance is inevitable. Increased operations, manpower requirements, manpower and increased workloads and employees under pressure, is one of the things that needs to be addressed.

The commitment of the management of the organization plays an important role for the implementation and continuity of the program without the need for conflict. Supervisors and maintenance of the main workforce for various and always provide awareness that the implementation of ergonomic aspects in the workplace is a good thing. The well-being of the members of the organization, the quality and productivity of the organization can earn well in turn to increase the profitability of the organization (Anema, Steenstra \& Urlings, 2003; Syahmil \& Selamat, 2020). Top management such as human resource managers, supervisors, line leaders, employees, experts or ergonomics, external consultants etc. can be used as members or teams in PE jobs in the workplace. The purpose of the involvement of several parties inside and outside the organization is to support each other such as their supervisors and managers, for work needs and product quality and productivity. PE implemented in the workplace requires shared attention to the problems they face, team development and feelings involved in decision making. This is due to increased communication between staff and management, reduction of risk factors, new processes and new designs for more and more productive work and activities (Hignett, Wilson \& Morris, 2005).

Future research could focus on aspects for participatory ergonomics studies that are appropriate to different job characteristics and organizational intoxication as well as employee commitment. The implementation and research of participatory ergonomics is not only subject to private organizations, but can even use public organizations that are specialized in the field of occupational safety and health. The involvement of various appropriate parties can call for variations of the findings to be contributed practically to the management of the organization and theoretically to future academics and researchers. Future search results can also be used as a guide for various parties to help the implementation of participatory ergonomics more effectively and with quality.

\section{Acknowledgements}

Special thanks to the Universiti Kebangsaan Malaysia that supported the writing of this article under Geran Galakan Penyelidik (GGP-2020-028). 


\section{References}

Archer, R., Borthwick, K., \& Tepe-Susanne. (2009). OS\&H a management guide. Engage Learning Australia 2009.

Alexander, D. C. (1986).The practice and management of industrial ergonomics. PrenticeHall, Inc. Engle Cliffs.

Anema, J. R., Steenstra, I. A., \& Urlings, I. J. M. (2003). Participatory Ergonomics as a Returnto-Work Intervention: A Future Challenge? American Journal of Industrial Medicine, 44, 273-281.

Angela, K. M. (2000). The ergonomics and organizational stress relationship. Dissertation of Doctor of Philosophy, Florida State University. United States.

Ashraf, S., Saedd, A., \& Bill, O. (2002). Development of a software package for ergonomic assessment of manufacturing industry. Computer \& Industrial Engineering Journal, 43, 485-493.

Bridger, R. S. (2003). Introduction to ergonomics. Taylor \& Francis Group. London and New York.

Broday, E. E. (2020). Participatory Ergonomics in the context of Industry 4.0: a literature review. Theoretical Issues in Ergonomics Science, 22(2), 237-250,

Burgess-Limerick, R. (2018). Participatory ergonomics: Evidence and implementation lessons. Applied Ergonomics, 68, 289-293.

Carayon, P., Xie, A., \& Kianfar, S. (2013). Human factors and ergonomics as a patient safety practice. BMJ Quality Safety, 23, 196-205.

Cole, D., Rivilis, I., Van Eard, D., Cullen, K., Irvin, E., \& Kramer, D. (2005). Effectiveness of participatory ergonomics interventions, a systematic review. Institute for work and health, Toronto.

Conway, P. M., Campanini, P., Sartori, S., Dotti, R., \& Costa, G. (2008). Main and interactive effects of shift work, age and work stress on health in an Italian sample care workers. Applied Ergonomics, 39(5), 630-639.

Dempsey, P. G., Wogalter, M. S., \& Hancock, P. A. (2000). What's in a name? Using terms from definitions to examine the fundamental foundation of Human Factors and Ergonomics science. Theoretical Issues in Ergonomic Science, 1, 3-10.

Eerd, D-van., Cole, D., Irvin, E., Mahood, Q., Keown, K., Theberge, N., Village, J., St.-Vincent, M., \& Cullen, K. (2010). Process and implementation of participatory ergonomic interventions: a systematic review. Ergonomics, 53 (10), 1153-1166.

Evanoff, B. A., Bohr, P. C., \& Wolf, L. D. (1999). Effects of a participatory ergonomics team among hospital orderlies. American journal of industrial medicine, 35(4), 358-365.

Fatin N. A. H., \& Selamat, M. N. (2020). Ergonomics Work System and Occupational Safety and Health Performance in The Manufacturing Sector. The Malaysian Journal of Ergonomics (MJEr), 2(1).

Fernandez, J. E. (1995). Ergonomics in the workplace. Facilities, 13(4), 20-27. MCB University Press.

Ghoudarzi, H., Vameghi R., Hosseini, Fouladi, S., Khammar, A., Poursadeqiyan, M., \& Kavari, S. H. (2019). Relationship Between Health and Safety Management Status and Job Satisfaction Among Employees of Rehabilitation Centers With Crisis Management Approach in Kohgiluyeh and Boyer-Ahmad Province. Health in Emergencies and Disasters Quarterly, 4(4),193-200.

Gyekye. (2005). Workers' Perceptions of Workplace Safety and Job Satisfaction. International Journal of Occupational Safety and Ergonomics 11(3), 291-302. 
Helander, M. G. (1997). The human factors profession. In: Salvendy G. Handbook of Human Factor and Ergonomics. Wiley, New York, USA, 3-16.

Hermans, V., \& Peteghem, J. V. (2006). The relationship between OSH and ergonomics: A 'mother-daugther' or 'sister-sister' relation? Applied Ergonomics, 37, 451-459.

Hignett, S., Wilson, J. R., \& Morris, W. (2005). Finding ergonomic solutions--participatory approaches. Occupational medicine (Oxford, England), 55(3), 200-207.

Jalaluddin, D. (2007). Industrial ergonomic. National Institute of Occupational Safety and Health. NIOSH. Bangi.

Jia Wern, M. K., \& Selamat, M. N. (2019). Sistem Kerja Ergonomik dan Prestasi Keselamatan dan Kesihatan Pekerjaan dalam Industri Pembuatan di Klang, Selangor. Jurnal Wacana Sarjana 3(1), 1-14.

Marcos, J. B., Ruiz-Frutos, C., Antônio-Renato, P. M., \& Adriano, D. (2021). A low-cost and efficient participatory ergonomic intervention to reduce the burden of work-related musculoskeletal disorders in an industrially developing country: an experience report, International Journal of Occupational Safety and Ergonomics, 27(2), 452-459.

Jong, A. M., \& Vink, P. (2002). Participatory ergonomic applied in installation work. Applied Ergonomic, 33, 439-448.

Kawakami, T., \& Kogi, K. (2005). Ergonomics Support for Local Initiative in Improving Safety and Health at Work: International Labour Organization Experiences in Industrially Developing Countries. Ergonomics 48(5), 581-590.

Khai, T. T., Kawakami, T., \& Kogi, K. (2005). Participatory Action Oriented Training: PAOT Programme Trainer's Manual. Centre for Occupational Health and Environment, Cantho.

Kogi, K. (2002). Work improvement and occupational safety and health systems: common features and research needs. Industrial Health, 40, 121-133.

Kogi, K. (2006). Participatory methods effective for ergonomic workplace improvement. Applied Ergonomics, 37, 547-554.

Kogi, K., \& Kawakami, T. (2002). JILAF POSITIVE Programme trainers' manual for occupational safety and health. International labour foundation, Japan.

Kogi, K., Yoshikawaa, T., \& Yoshikawa, E. (2015). The link between stress prevention checkpoints and ergonomic checkpoints at the workplace. Proceedings 19th Triennial Congress of the IEA, Melbourne 9-14 August 2015.

Kogi, K. (2010). Roles of occupational health good practices in globalization". Journal of Occupational Safety and Health, 18, 172-181.

Kogi, K. (2012a). Practical ways to facilitate ergonomics improvements in occupational health practice. Human Factors, 54(6), 890-900.

Kogi, K. (2012b). Roles of participatory action-oriented programs in promoting safety and health at work. Safety and Health at Work, 3, 155-165.

Korunka, C., Dudak, E., Molnar, M., \& Hoonakker, P. (2010). Predictors of a successful implementation of an ergonomic training program. Applied Ergonomics, 1-8.

Kuorinka, I. (1997). Tools and means of implementing participatory ergonomics. International Journal Industrial Ergonomics, 19, 267-270.

Kuorinka, I., \& Patry, L. (1995). Participation as a means of promoting occupational health. International Journal Industrial Ergonomics, 15, 365-370.

Loo, H. S., \& Richardson, S. (2012). Ergonomics Issues in Malaysia. Journal of Social Sciences, 8(1), 61-65.

Macie, R. (1998). Participatory ergonomics and organizational change. International Journal 
Industrial Ergonomics, 22, 319-325.

Mahdavi, N., Motlagh, S. M., \& Darvishi, E. (2019). Implementation of Ergonomic Interventions using Participatory Program Method of PErforM. Iranian Journal of Ergonomics. 7 (2):19-29

Mansfield, J. A., \& Armstrong, T. G. (1997). American Industrial Hygiene Association Journal, $58(2), 138-144$.

Matthews, R. A., Gallus, J. A., \& Henning, R. A. (2011). Participatory ergonomics: Development of an employee assessment questionnaire. Accident Analysis and Prevention, 43(1), 360-369.

Mavis, I., Abdul-Rahman, A., \& Mohd-Tamrin, S. B. (2014). Ergonomic risk reduction: In OSH certified and uncertified automotive parts manufacturing industry workers. MiddleEast Journal of Scientific Research, 22(9), 1272-1280.

Azman, M. A. A., \& Selamat, M. N. (2019). Sistem Kerja Ergonomik dan

Prestasi Keselamatan dan Kesihatan Pekerjaan dalam Industri Pembuatan. Jurnal Wacana Sarjana 3(2), 1-1.

Syahmil, M. N., \& Selamat, M. N. (2020). Hubungan Antara Sistem Kerja Ergonomik dan

Prestasi Keselamatan dan Kesihatan Pekerjaan. Jurnal Wacana Sarjana 4(1), 1-13.

Nagamachi, M. (1995). Requisites and practice of participatory ergonomics. International Journal of Industrial Ergonomics, 15, 371-377.

Noblet, A., \& Lamontagne, A. D. (2006). The role of workplace health promotion in addressing job stress. Health Promotion International, 21(4), 346-353.

Noro, K., \& Imada, A. (1991). Participatory Ergonomics. Taylor and Francis, London.

Nur Azreen, R., \& Selamat, M. N. (2020). Sistem Kerja Ergonomik Prestasi Keselamatan dan Kesihatan Pekerjaan di Industri Pembuatan Malaysia. Jurnal Wacana Sarjana 1-10.

Parsons, K. C. (2000). Environmental ergonomics: A review of principles, method and models. Applied Ergonomics, 31, 581-594.

Punnett, L., Warren, N., Henning, R., Nobrega, S., \& Cherniack, M. (2013). CPHNEW Research Team. Participatory ergonomics as a model for integrated programs to prevent chronic disease. Journal Occupational Environment Medicine, 55, 19-24.

Richardson, B., \& Hignett, S. (1994). Risk assessment-myth or method? In: Ergonomics and health \& safety. Working together to meet the challenge of the new EC directives. Occupational Medicine. 206.

Rivilis, I., Van-Eard, D., Cullen, K., Cole, D. C., Irvin, E., Tyson, J., \& Mahood, Q. (2008). Effectiveness of participatory ergonomic interventions on health outcomes: $A$ systematic review. Applied Ergonomics, 39, 342-358.

Rowan, M. P., \& Wright P. C. (1994). Ergonomic is good for business. Work Study, 43(8), 712. MCB University Press.

Sandra, S., Beach, J. R., Aw, T-C., \& Sheikh-Ahmed, K. (2001). Occupational health research priorities in Malaysia: a Delphi Study. Occupational and Environment Medicine, 58, 426-431.

Sara, Cervai., \& Federica, Polo. (2017): The impact of a participatory ergonomics intervention: the value of involvement, Theoretical Issues in Ergonomics Science. DOI: 10.1080/1463922X.2016.1274454

Selamat, M. N. (2016). Ergonomic work system and occupational safety and health performance: Mediating effect of psychosocial work factor. Ph.D Thesis, Malaysia Universiti Sains Malaysia. Penang. 
Selamat, M. N. (2013). The determinant of OSH performance: A study on ergonomic work system. Journal Occupational Environmental Medicine, 70.

Selamat, M. N., \& Surienty, L. (2012). Participatory ergonomic: Mechanism to improve workers productivity. Proceeding of 13th Malaysia - Indonesia Conference on Economics, Management, and Accounting. Palembang, Indonesia. October 18-20, 2012. ISBN 977208640400.

Selamat, M. N., Mukapit, M., Aziz, S. F. A., \& Zafir K, M. M., (2019). Re-definition of Occupational Safety and Health Performance in Malaysian Manufacturing Industry. International Journal of Recent Technology and Engineering (IJRTE) ISSN: 2277-3878, 8, 2S10.

Selamat, M. N., Akhir, N. M., Abdul Aziz, S. F., Jaaffar, A. H., \& Baker, R. (2020). Reliable Dimensions of Ergonomic Work System in the Malaysian Manufacturing Industries. International Journal of Academic Research in Economics \& Management Sciences. 9(2), 102-112.

Shaliza, A. M., Shahrul, K., Zalinda, O., \& Mohzani, M. (2009). The effect of ergonomics applications in work system on mental health of visual display terminal workers. European Journal of Scientific Research, 31(3), 341-354.

Sheley, E. (1995). Preventing repetitive motion injuries. HR Magazine, 40, 57-59.

Smith, M. J., \& Carayon, P. S. (2000). Work organization and ergonomics. Applied Ergonomics 31, 649-662.

St-Vincent, M., Bellemare, M., Toulouse, G., \& Tellier, C. (2006). Participatory ergonomic processes to reduce musculoskeletal disorders: Summary of a Québec experience. Work: A Journal of Prevention, Assessment and Rehabilitation, 27 (2), 123-135.

Sundin, A., Christmansson, M., \& Larsoon, M. (2004). A different perspective in participatory ergonomics in product development improves assembly work in the automotive industry. International Journal of Industrial Ergonomics, 33, 1-14.

Tappin, D. C., Vitalis, A., \& Bentley, T. A. (2016). The application of an industry level participatory ergonomics approach in developing MSD interventions. Applied Ergonomics, 52, 151-159.

Tsutsumi, A., Nagami, M., Yoshikawa, T., Kogi, K., \& Kawakami, N. (2009). Participatory intervention for workplace improvements on mental health and job performance among blue-collar workers: a cluster randomized controlled trial. Journal Occupational Environment Medicine, 51, 554-563.

Vink, P., Peeters, M., Grundemann, R. W. M., Smulders, P. G. W., Kompier, M. A. J., \& Dul, J. (1995). A participatory ergonomics approach to reduce mental and physical workload. International Journal of Industrial Ergonomics, 15, 389-396.

Vink, P., \& Wilson, J. R. (2003). Participatory ergonomics. In: Proceeding of the XVth Triennial Congress of the International Ergonomics Association and The 7th Joint conference of the Ergonomics Society of Korea/Japan Ergonomics Society, 'Ergonomics in the Digital AGE', 24-29. Seoul, Korea.

Westgaard, R. H., \& Winkel J. (1997). Review article ergonomic intervention research for improved musculoskeletal health: A critical review. International Journal Industrial Ergonomics, 20, 463-500.

Wilson, J. R., Wilson, J. R., \& Corlett, E. N. (1995). Ergonomics and participation. In: Evaluation of Human Work: A Practical Ergonomics Methodology, 2nd Edition. Taylor and Francis, London, 1071-1096.

Wilson, J. R., \& Haines, H. M. (1997). Participatory Ergonomics. In: Salvendy G. Handbook of 
Human Factors and Ergonomics, 2nd Edition. John Wiley and Sons, New York. 490-513. Wilson, J. R., Haines H., \& Morris, W. (2005). "Participatory Ergonomics," in Evaluation of Human Work, 3rd ed., J. R. Wilson and C. Nigel, Eds. Taylor \& Francis, 2005, 933-949. Yakubu, D. M., \& Bakri, I. M. (2013). Evaluation of safety and health performance on construction sites (KL). Journal of Management and Sustainability, 3(2).

Yeow, P. H. P., \& Rabindra, N. S. (2003). Quality, productivity, occupational health, and safety and cost effectiveness of ergonomic improvements in the test workstations of an Electronic Factory. International Journal of Industrial Ergonomics, 32, 147-163.

Zafir, M. M. (2008). Perhubungan antara stesen kerja ergonomik dan stres: Kajian terhadap operator pengeluaran di organisasi multinasional di Malaysia. Unpublished doctoral dissertation, Universiti Teknologi Malaysia, Johor, Malaysia.

Zafir, M. M. (2009). Persepsi Organisasi Multinasional di Malaysia Terhadap Pengurusan Stesen Kerja Ergonomik. Journal of Social Sciences and Humanities, 4(1), 137-146.

Zafir, M. M., Nor-Liza, A., \& Zizah, C. S. (2013). Ergonomics and stress at workplace: engineering contributions to social sciences. Jurnal Pengurusan, 37, 125-131. 